\title{
Seed characteristics and dispersal of dimorphic fruit segments of Cakile maritima Scopoli (Brassicaceae) population of southern Brazilian coastal dunes
}

\author{
CÉSAR VIEIRA CORDAZZO ${ }^{1}$
}

(received: May 5, 2005; accepted: May 11, 2006 )

\begin{abstract}
Seed characteristics and dispersal of dimorphic fruits segments of Cakile maritima Scopoli (Brassicaceae) population of southern Brazilian coastal dunes). Cakile maritima occurs sporadically along the southern Brazilian coast, where it is restricted to more protected sites at the base of foredunes. Somatic dimorphism in C. maritima is manifested as morphologically distinct upper and lower fruit segments (silicules). The two morphs were tested for differences in size, number of seeds, dispersal ability and natural establishment. In the C. maritima population of southern Brazil, the lower silicule has more seeds than upper silicule, and lower seeds are more likely to abort than the upper ones. Seeds from upper segments were significantly larger than those from lower ones; however, their mass ranges overlap. The mean silicule mass was not significantly different from both segments, but the silicule/seed mass ratio from upper and lower segments was significantly different. Both segments had high ability to float in sea water, more than $50 \%$ were still afloat after 70 days. Nevertheless, dispersal occurs mainly to landward due to dominant wind action. Most of the seedlings were restricted to within a one-metre radius of the mother plant, and were principally derived from lower fruit segments.
\end{abstract}

Key words - Cakile, dimorphic fruits, dispersal, seed production

RESUMO - (Características das sementes e dispersão dos segmentos de frutos dimórficos de uma população de Cakile maritima Scopoli (Brassicaceae) nas dunas costeiras do Sul do Brasil). Cakile maritima ocorre esporadicamente ao longo da costa Sul do Brasil, onde é encontrada restrita aos locais mais protegidos na base das dunas frontais. O dimorfismo somático é manifestado como segmentos de frutos (silículas) superior e inferior, morfologicamente distintos. As sementes dos dois tipos de segmentos foram avaliadas quanto ao tamanho, número, capacidade de dispersão e estabelecimento em condições naturais. Na população de C. maritima no Sul do Brasil as silículas inferiores apresentaram maior número de sementes do que as siliculas superiores, e as sementes das silículas inferiores foram mais abortadas que as das superiores. As sementes dos segmentos superiores foram significativamente maiores do que aquelas dos segmentos inferiores; entretanto ocorreu uma sobreposição nos pesos entre elas. O peso médio das silículas dos dois segmentos não difere significativamente, mas a razão peso das silículas / peso das sementes foi significativamente diferente para os segmentos superior e inferior. Ambos segmentos apresentaram grande habilidade de flutuar em água salgada, superior a 50\% após 70 dias. Todavia, a dispersão dos segmentos dos frutos ocorre principalmente em direção ao continente através da ação do vento. A maioria das plântulas encontradas no ambiente natural se encontrava restrita num raio de um metro da planta-mãe, e era originada principalmente de sementes dos segmentos inferiores dos frutos.

Palavras-chave - Cakile, dimorfismo de frutos, dispersão, produção de sementes

\section{Introduction}

Cakile maritima Scopoli (Brassicaceae), "sea rocket”, is a succulent annual or biennial species narrowly restricted in habitat to the coastal strandline, but widely distributed throughout the world (Barbour 1972). The species occurs sporadically along the southeastern Brazilian coast, but is restricted to more

1. Fundação Universidade Federal do Rio Grande, Departamento de Oceanografia, Laboratório de Ecologia Vegetal Costeira, Caixa Postal 474, 96201-900 Rio Grande, RS, Brazil. doccesar@furg.br protected sites at the base of frontal dune ridges (Cordazzo 1985, Seeliger 1992, Cordazzo \& Seeliger 1993). It is native to the shores of the Mediterranean Sea, and was introduced into South America last century in the ballast of ships plying between European and South American ports (Rodman 1986).

A limited number of families of higher plants, such as Brassicaceae, Chenopodiaceae, Poaceae, and Asteraceae, appears to have somatic seed polymorphism (Baskin \& Baskin 1976, Fenner 1985). This phenomenon is the production of seeds or fruits with different morphologies or germinative behaviour on different parts of the same plant, and it is a somatic differentiation rather than the result of genetic 
segregation (Harper 1977). These variations are frequently accompanied by differences in seed size (Sorenson 1978), colour (Williams \& Harper 1965), external structure (Williams \& Harper 1965), dispersibility (Sorenson 1978, Payne \& Maun 1981), germination requirements (Berger 1985), and growth (Maun \& Payne 1989). Somatic dimorphism in C. maritima consists of two morphological distinct types of fruit segments, upper and lower (figure 1). The upper fruit segments are deciduous and may disperse long distances by water waves and currents and for short distances by rolling caused by winds. The lower fruit segments usually remain attached to the parent plant and are consequently buried by wind-blown sand, thereby forming clumps of seedlings in the next growing season (Barbour 1972, Keddy 1982).

The number of seeds in C. maritima varies between upper and lower fruit segments (Barbour 1970). Maun et al. (1990) found that seed size in C. edentula varies with position within the fruit and germination differs for upper and lower segment seeds.

The aims of this work were (a) to determine seed production and seed size of the two types of fruit segments; (b) to examine the modes of dispersal of the dimorphic fruit segments of C. maritima population in southern Brazilian coastal dunes.

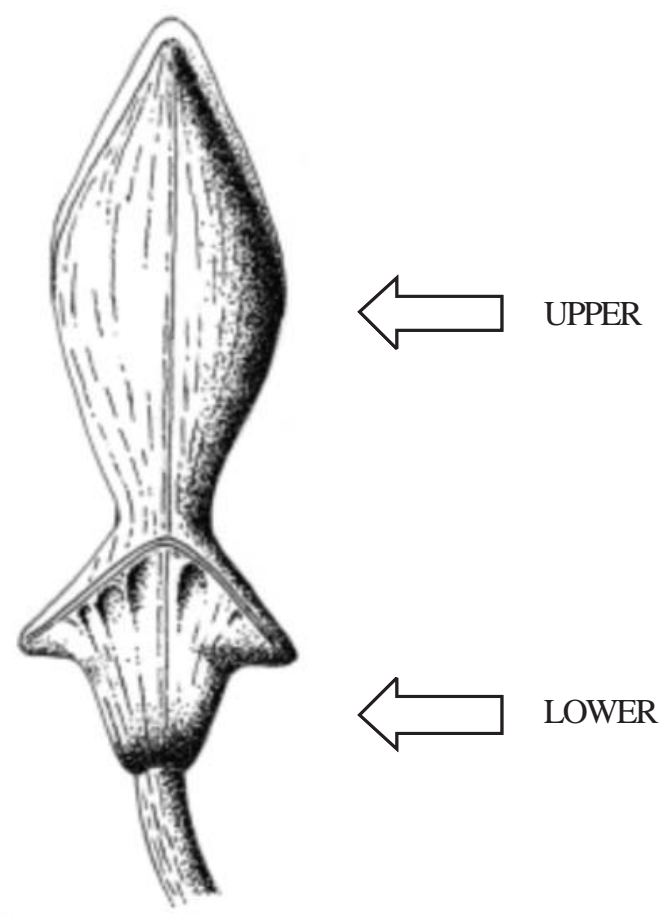

Figure 1. The distinctive fruit of Cakile maritima Scopoli an indehiscent, hard-corky, two-segmented silicule (upper and lower).

\section{Material and methods}

To determine reproductive output per plant, 25 plants randomly selected of Cakile maritima Scopoli were harvested in March (end of summer) from plants near Sarita Lighthouse $\left(32^{\circ} \mathrm{S}\right.$ and $52^{\circ} \mathrm{W}$ ) and packed in individual bags. Later, in the laboratory, the number of fruits and number of seeds from each plant were recorded. A randomly selected sub-sample of 560 fruits (silicules) was separated into upper and lower segments, and each segment was split to remove its seed. The number of seeds in each segment was recorded.

Seedlings of $C$. maritima ( 5 days old) were individually planted in $26 \mathrm{~cm}$ diameter plastic pots filled with 4:1 sand and compost soil mixture. All pots were maintained in a glasshouse until they produced flowers and fruits. Plants were watered daily with freshwater and every two months each plant received $200 \mathrm{~mL}$ of nutrient solution (NPK 7:7:7, $1 \mathrm{~g} 1000 \mathrm{~mL}^{-1}$ ).

The mass and length of 300 seeds and silicules from each of upper and lower fruit segments of C. maritima, selected at random, were recorded with an electronic balance and with calipers, respectively.

The potential for dispersal by water of fruit segments (upper and lower) was assessed by determining buoyancy, using methodology similar to that used by Maun (1985) and Maun \& Payne (1989). Four replicates, each of 100 fruits, were placed in individual $4,000 \mathrm{~mL}$ beakers containing seawater, and maintained at a controlled room temperature of $20 \pm 2^{\circ} \mathrm{C}$. The water was constantly agitated by bubbling air through it to avoid stagnation and simulate wave action. The number of fruits still afloat was counted every 24 hours for a maximum of 70 days.

In order to determine the dispersal capacity of C. maritima seeds, four-weeks old plants were planted in the foredune areas, individually, at locations where C. maritima plants had been previously absent. Six months later, the plants which had survived and produced fruits were marked with wooden stakes. The seedlings from the progeny were mapped (position and distance) in relation to their mother plants and carefully removed. In most cases the silicule remained attached near to the junction of the hypocotyl and the root, which permitted identification of the type of fruit (upper or lower) from which it had originated.

Student's "t-test" was used to compare differences in seed mass, and dimensions between dimorphic fruits and also the dispersal of the two fruit segments. Additionally, test comparing two proportions (Zar 1984) was used to compare the number of seeds produced in each type of fruit segment.

\section{Results}

Late summer was the best time to assess the reproductive capacity of Cakile maritima Scopoli in the southern Brazilian coastal dunes, because most fruits were close to maturity and the upper fruit segments 
had not yet detached from the lower ones. Fruit production per plant was highly variable with range of 15 to 3,561 fruits, which indicates a high plasticity among plants. The mean total number of seeds (upper + lower) per plant also showed high variation, with a range of 22 to 3,269 seeds, and an average ( \pm standard deviations) of $1011.5 \pm 214.6$.

Usually each fruit segment contained a single seed, but sometimes it contained none (i.e. the seed had aborted) or up to three normal seeds (table 1). The lower fruit segments contained more than two seeds more often than the upper one, and lower seeds showed a tendency to be more frequently aborted (11.4\%) than upper ones (9.3\%), however these values was not statistically different $(P=0.2489)$.

The annual C. maritima completed its growth and reproduction in six months, producing fruits and seeds. Experiments in the glasshouse with the addition of nutrients produced seed masses significantly greater for both fruit segments, with an average of (upper) $6.0 \pm 0.14 \mathrm{mg}$; (lower) $4.9 \pm 0.18 \mathrm{mg}$ relative to those in the field (upper) $4.2 \pm 0.12 \mathrm{mg}$; (lower) $3.9 \pm 0.11 \mathrm{mg}$, respectively.

The seed lengths from upper segments was $4.1 \pm$ $0.1 \mathrm{~mm}$ (2.6 to $5.1 \mathrm{~mm}$ ), while those of lower ones was $3.8 \pm 0.2 \mathrm{~mm}$ (3.0 to $5.0 \mathrm{~mm}$ ). In the southern Brazilian population, seeds from upper segments were significantly heavier than from lower ones, with a mean of $4.2 \pm 0.1 \mathrm{mg}$ and $3.9 \pm 0.1 \mathrm{mg}$, respectively (table 2 ). However, their length and mass ranges overlap (figure 2). The mean silicule mass was not significant different between both segments (table 2), but the silicule/seed ratio from upper and lower segments was significantly different (mean \pm standard deviation)(2.9 \pm 0.7 and $3.3 \pm 0.9$ ), respectively. Seed mass was significantly correlated with seed length for both fruit segments $\left(r=0.834, F_{\text {upper }}=107.87, P<0.001\right)$; $(r=$ $\left.0.768, F_{\text {lower }}=51.77, P<0.001\right)$.

The dispersal of the fruit segments was both perpendicular to and lateral along the beach (figure 3)

Table 1. Percentage of the number of seeds per fruit segment of Cakile maritima Scopoli from a southern Brazilian coastal dune. Empty segments were recorded as abortive $\left(^{*}\right)(n=560$ fruits), (ns) = not significant.

\begin{tabular}{lccccc}
\hline & \multicolumn{5}{c}{ Number of seeds per segment } \\
\cline { 2 - 6 } Segment & $0\left(^{*}\right)$ & 1 & 2 & 3 & 4 \\
\hline Lower & $11.4 \%$ & $68.8 \%$ & $19.0 \%$ & $0.7 \%$ & $0.1 \%$ \\
Upper & $9.3 \%$ & $82.7 \%$ & $8.0 \%$ & & \\
& $(n s)$ & $P<0.001$ & $P<0.001$ & & \\
\hline
\end{tabular}

but the perpendicular dispersion was greater than lateral movement $(t=5.74 ; P<0.001)$, with means of $60.9 \pm$ $6.25 \mathrm{~cm}$ and $23.7 \pm 1.78 \mathrm{~cm}$, respectively. The mean distances of dispersal of fruit segments of $C$. maritima were significantly different $(t=7.69 ; P<0.001)$ at 67.6

Table 2. Mean ( \pm standard error) of seed length and mass, silicule mass and silicule/seed ratio of fruits (upper and lower) of a Cakile maritima Scopoli population from a southern Brazilian coastal dune ( $n=300$ fruits). Different letters in each column are significant different according to "t-test" (Student) at 5\% significance level. (ns = not significant).

\begin{tabular}{lcccc}
\hline Segment & $\begin{array}{c}\text { Seed } \\
\text { length }(\mathrm{mm})\end{array}$ & $\begin{array}{c}\text { Seed } \\
(\mathrm{mg})\end{array}$ & $\begin{array}{c}\text { Silicule } \\
(\mathrm{mg})\end{array}$ & $\begin{array}{c}\text { Silicule/Seed } \\
\text { Ratio }\end{array}$ \\
\hline Lower & $3.8 \pm 0.2$ & $\begin{array}{c}3.9 \pm 0.1 \\
\text { (a) }\end{array}$ & $11.0 \pm 2.2$ & $\begin{array}{c}3.3 \pm 0.9 \\
\text { (a) }\end{array}$ \\
Upper & $\begin{array}{c}4.1 \pm 0.1 \\
\text { (ns) }\end{array}$ & $\begin{array}{c}4.2 \pm 0.1 \\
\text { (b) }\end{array}$ & $\begin{array}{c}10.7 \pm 1.9 \\
(\mathrm{~ns})\end{array}$ & $\begin{array}{c}2.9 \pm 0.7 \\
\text { (b) }\end{array}$ \\
& $t=0.98$ & $t=2.45$ & $t=-0.91$ & $t=2.17$ \\
\hline
\end{tabular}
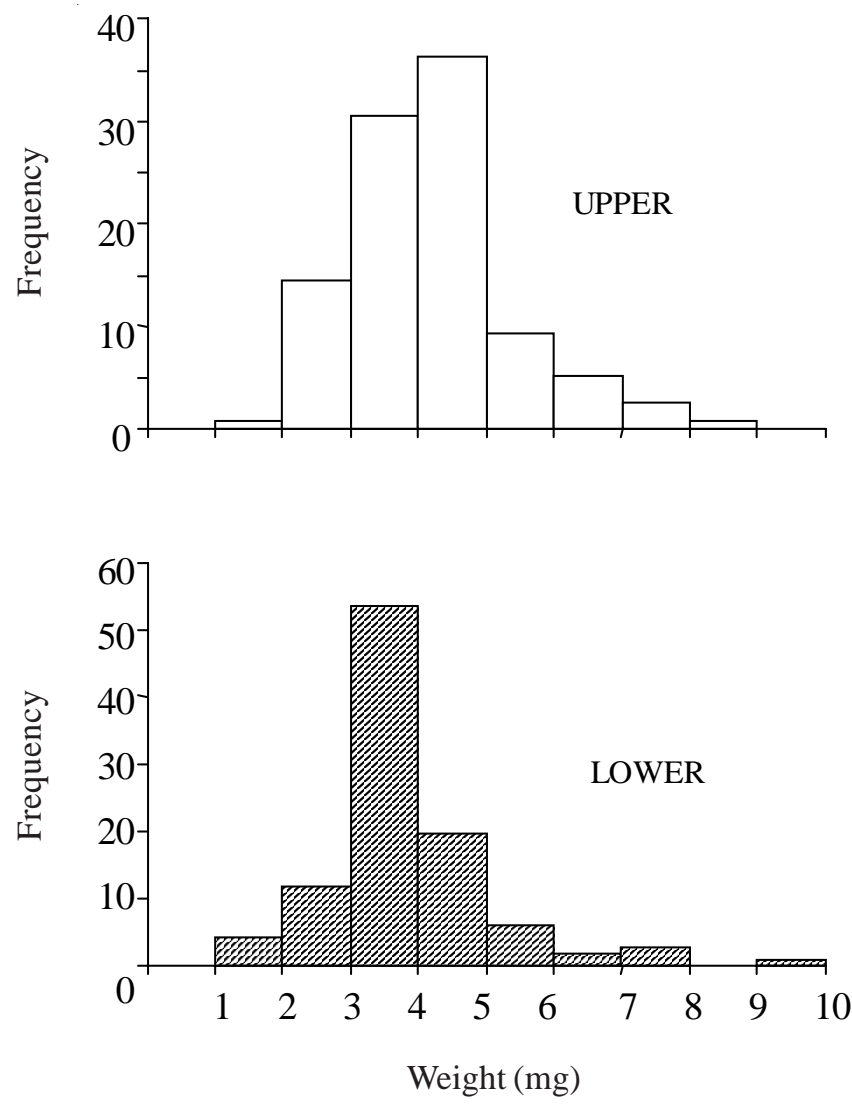

Figure 2. Frequency distribution of seed mass (mg) from different fruit segments of Cakile maritima Scopoli population of southern Brazilian coastal dune: upper segments (open, $n=120$ ); lower segments (hatched, $n=120$ ). 
\pm 6.3 and $27.8 \pm 4.0 \mathrm{~cm}$ for upper and lower fruits, respectively (figure 4). Some fruits from upper segments had dispersed by wind to a maximum detected distance of $723 \mathrm{~cm}$ from the parent plant.

The upper and lower fruit segments of C. maritima showed high buoyancy of $60 \%$ and $58 \%$, respectively, after 70 days in agitated seawater (figure 5). No

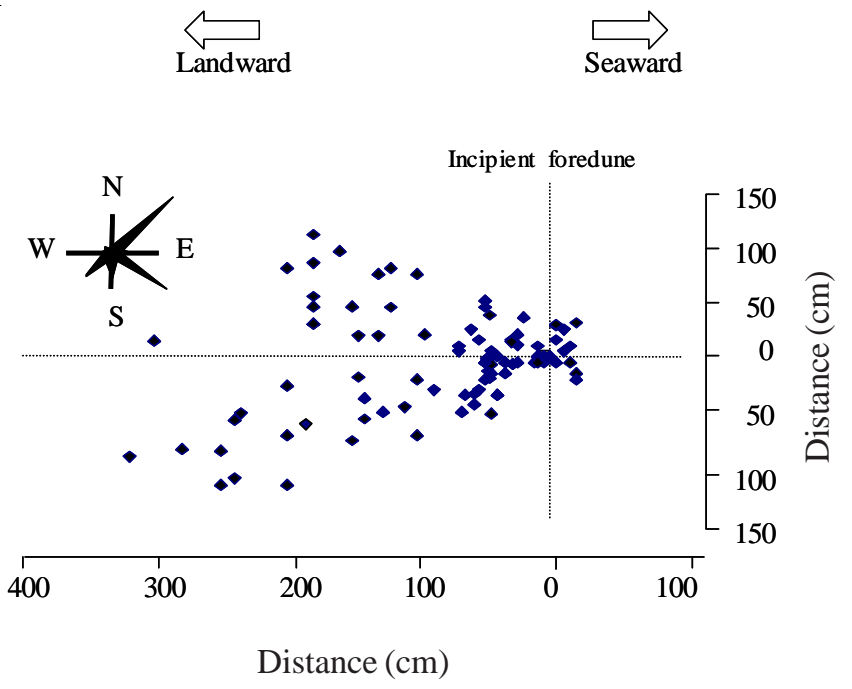

Figure 3. Distribution of seedlings around mother plants of Cakile maritima Scopoli in relation to dominant NE and SE wind directions (star symbol plot) in southern Brazilian coastal dunes during the experimental period $(n=92)$. The length of the rays in the star symbol plot represents the proportional frequencies of wind directions.

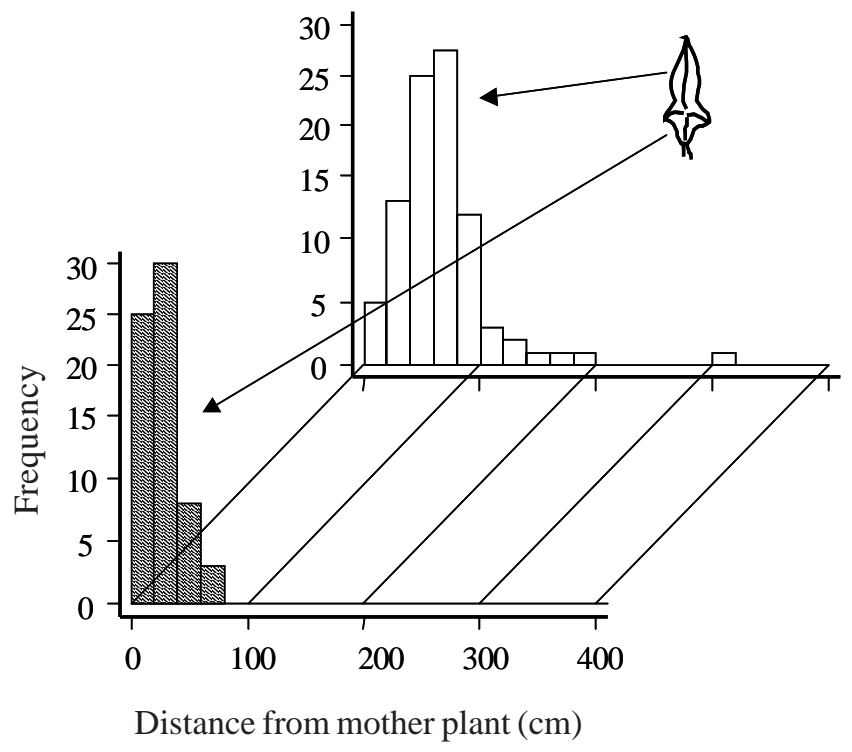

Figure 4. Frequency of seedling dispersal away from mother plants of Cakile maritima Scopoli in a southern Brazilian coastal dune: = lower fruits; open area $\square=$ fruits $(n=100)$. significant differences were observed between upper and lower fruit segments $(t=0.297 ; P<0.5)$ in buoyancy. The majority of upper and lower fruit segments remained afloat after the first 20 days of agitation. However, after 20 days the number of fruit segments that sank increased. No germination of either type of fruit segment was recorded while they were floating in seawater.

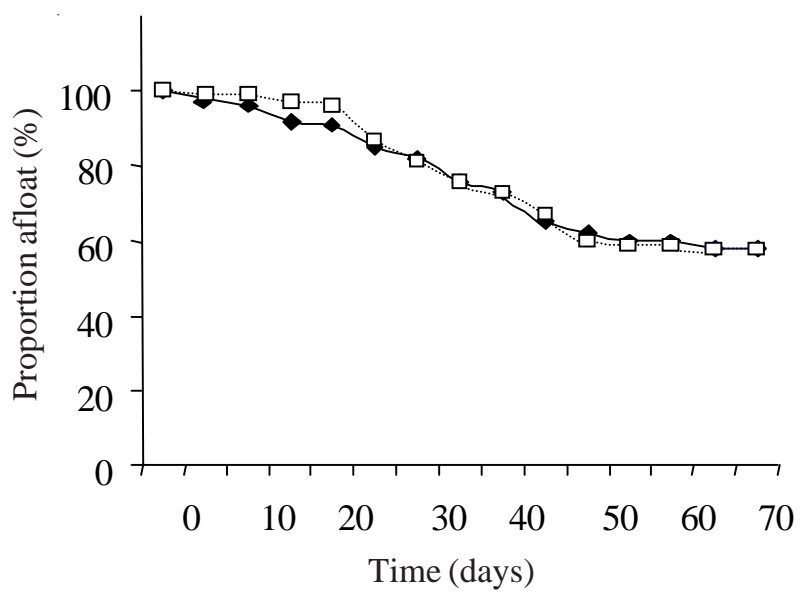

Figure 5. Buoyancy of Cakile maritima Scopoli fruits: filled diamonds one lower fruit segments, $n=100$; open empty rectangles one upper fruit segments, $n=100$. $-\checkmark-=$ Lower fruits; - - $=$ Upper fruits.

\section{Discussion}

The high variability in seed production of Cakile maritima Scopoli in the southern Brazilian population is probably due in part to continuous germination through the year (Cordazzo 1994), which creates a mixed agestructure. Additionally, a high phenotypic plasticity is combined with microsite environmental variability that may vary in moisture content, nutrient status and organic detritus, similar to the situation in C. edentula (Bigel.) Hook. on Canadian lake shores (Hawke \& Maun 1989).

The large number of aborted and multiple seeds in lower (proximal) segments in relation to upper (distal) segments, was reported in several works (Salisbury 1942, Barbour 1970, Rodman 1974, Maun et al. 1990), thus indicating that lower seeds are being selectively aborted. Hawke \& Maun (1989) reported that the abortion of seeds in C. edentula may be of adaptive significance because larger quantity of nutrients would be available for fewer ovules thus increasing or maintaining their size above a certain minimum probably at expense of the number of seeds. Upper seeds were slightly larger 
than lower seeds, which is characteristic of seeds in all Cakile taxa (Rodman 1974). The frequency distribution of seed mass was positively skewed for both upper and lower seeds. Ernest (1985) suggested that a skewed distribution indicates stress which may result from a shortage or excess of moisture, nutrients, salt content, or other environmental factors.

Both upper and lower seeds of C. maritima in southern Brazil were lighter than those recorded in other populations by Salisbury (1942) for central European material (upper $9.7 \mathrm{mg}$; lower $8.5 \mathrm{mg}$ ), by Barbour (1970) for Californian specimens (upper $8.2 \mathrm{mg}$; lower $6.0 \mathrm{mg}$ ), and by Hocking (1982) for south-western Australia (upper $11.9 \mathrm{mg}$; lower $11.0 \mathrm{mg}$ ). Hocking (1982) suggested that differences between seeds from different places may be a function of the higher solar radiation and thus greater photosynthesis, or due to a large-seeded ecotype. The first hypothesis is questionable, because seeds of $C$. maritima from southern Brazil were lighter than seeds from south-western Australia and California (USA) at similar latitude.

Shortage of nutrients and competition with other plants are two factors that may cause reduction in plant size which initially is reflected in reduction of reprodutive output (Keddy 1982, Cody \& Cody 2004). Cakile habitat is usually subjected to occasional flooding by sea water, continuous salt spray and litter deposition, which together provide Cakile with extra nitrogen and phosphorus (Garcia-Novo 1976, Pakeman \& Lee 1991b). Pakeman \& Lee (1991a) found that C. maritima on the west coast of Wales showed marked differences in growth dependent on its position of establishment on sandy shores. Large, rapidly growing plants are associated with sand containing macroalgal litter, whereas small stunted plants are found on foredunes above the limit of tidal inundation. Probably the small mass of Cakile seeds from southern Brazil reflects a low nutrient status (Costa et al. 1991, Cordazzo 1994), because this population occurs not in a strandline habitat, but in the more stable conditions encountered at the base of foredunes (Seeliger 1992) where competition for nutrient may occur with the perennial grass Panicum racemosum (Beauv.) Spreng. This hypothesis was supported by the results, where plants from the southern Brazil population were grown in different conditions: in the natural environment versus in a glasshouse, where they received nutrient solution. The mean seed mass of both segments from cultivated plants was significanty larger than plants from natural environment.

An additional explanation for the small seed mass of plants from southern Brazil in relation to other populations may be because seeds from fruit segments occupied by twin seeds are highly significantly lighter than seeds from single-seeds fruits (Janzen 1978), reflecting strong competition for resources among siblings within a fruit. For instance seeds from both segments of $C$. maritima from southern Brazil were more frequently multiple (lower $19.8 \%$; upper $8 \%$ ) than other populations, as reported by Barbour (1970) from California (lower 7\%; upper 4\%).

Fruits of Cakile are well adapted for water dispersal, because the presence of spongy tissue in the silicule makes them buoyant in seawater for long periods of time (Maun et al. 1990). Several papers reported this ability (Barbour 1970, Rodman 1974, Davy \& Figueroa 1993, Andersen 1993). Guppy (1917) estimated that fruits of C. edentula (Bigel.) Hook. have a potential to travel $208-272 \mathrm{~km}$ in seawater, and C. maritima extended its range about $625 \mathrm{~km}$ in less than 30 years on the western coast of the North America (Barbour \& Rodman 1970).

Both fruit segments of $C$. maritima from South Brazil floated for long periods in seawater, paralleling the results obtained by Maun \& Payne (1989) from Canadian material. On the other hand, Ignaciuk \& Lee (1980) reported that only a small proportion (4\%) of C. maritima fruits remained afloat after 30 days, and Payne \& Maun (1981) found that only the overwintered fruit segments showed exceptional floating ability. The apparent contradiction between these findings may arise from the fact that the fruits from southern Brazil had smaller seeds and more spongy tissue in the silicule than the other populations (see the ratio silicule/seed mass table 2).

The dispersibility of dimorphic fruit segments of Cakile may be an adaptation and the species appears to use three modes of dispersal: passive, long-distance movement of fruit, and local dispersal by wind (Payne \& Maun 1981). In the C. maritima population in the southern Brazil, the passive mode and local dispersal by wind are the two principal mechanisms of dispersal. Although, both fruit segments appear to possess high potential to disperse by water because they had floating ability, this dispersal is negligible in southern Brazilian population. There is good evidence to support this contention; (a) since the first record in the southern Brazil (Cordazzo 1985), C. maritima has not expanded its range along the coast; (b) it occurs only in some patches restricted to more protected areas, free of normal storm tides (Cordazzo \& Seeliger 1993), which can disperse seeds; (c) the dispersal occurs more frequently in the landward direction, by wind action, similar to results 
observed by Keddy $(1981,1982)$ in C. edentula. He reported that the landward populations could only exist because of the annual dispersal of seeds from seawards. Watkinson's model (1985) of Keddy's data shows that the abundance of individuals along the gradient is dependent upon the interaction between various densitydependent and density-independent processes.

Most of the seedlings which germinate in spring were restricted to within one-meter radius of mother plant, and mainly originated from lower fruit segments. This result agrees with previous results (Barbour 1970, 1972, Rodman 1974, Keddy 1980, 1982, Payne \& Maun 1981) and reflects the property of the lower fruit segment (which remains attached in the parent) to remain in the proven and productive habitat (Donohue 1998). The upper fruit segments can be dispersed by wind for long distances, even though they do not possess any accessory structure (such as a sail) for wind dispersal. In southern Brazil the dominant winds are from NE and SE (Seeliger 1992) and the seedling distribution follows a landward path at SW and NW directions. Although we found seedlings (from upper fruit) $723 \mathrm{~cm}$ from parent plant, most upper seeds are carried only 1 to $2 \mathrm{~m}$ landward, mainly because the obstruction caused by the presence and high cover of the grass Panicum racemosum Spreng., which restricts wind transport (Cordazzo \& Davy 1994).

In conclusion, fruit segments of Cakile maritima are typically one-seeded, however, sometimes both segments are multispermous (usually two-seeded) or abortive (Rodman 1974). Lower fruit segments are more often multispermous or abortive than upper segments, while three- and four-seeded segments are quite rare (Rodman 1974). The position of dimorphic fruits of Cakile influence their seed mass (Barbour 1970). The seeds from lower fruits have a significantly lighter mass than upper seeds, which may result from competition between ovules for limited resources, early or late fertilization of ovules and possibly hormonal control of fruit development (Hawke \& Maun 1989). Fruit dimorphism in C. maritima may be of adaptive significance mainly for seedling establishment and seed dispersion. Seedling establishment may be affected by seed mass because large seeds of $C$. maritima positively affect germination rates (Cordazzo 1994). Furthermore, survival of seedlings from large seeds tends to be higher than from small seeds (Maun \& Payne 1989). This behavior appears to be an adaptation to establishment in areas with active sand burial (Zhang \& Maun 1992, Cordazzo 2002) as is common in Cakile habitats. Additionally, dimorphic fruit segments reflect two modes of dispersal. The upper fruit segment is shed and than dispersed by wind or water, whereas the lower fruit segment remains attached to the parent plant, thereby forming clumps of seedlings in a "tried and true" habitat (Barbour 1972).

\section{References}

ANDERSEN, U.V. 1993. Dispersal strategies of Danish seashore plants. Ecography 16:289-298.

BARBOUR, M.G. 1970. Germination and early growth of the strand plant Cakile maritima. Bulletin of the Torrey Botanical Club 97:13-22.

BARBOUR, M.G. 1972. Seedling establishment of Cakile maritima at Bodega Head, California. Bulletin of the Torrey Botanical Club 99:11-16.

BARBOUR, M.G. \& RODMAN, J.E. 1970. Saga of the west coast sea-rockets: Cakile edentula ssp. californica and C. maritima. Rhodora 72:370-386.

BASKIN, J.M. \& BASKIN, C.C. 1976. Germination dimorphism in Heterotheca subaxillaris var. subaxillaris. Bulletin of the Torrey Botanical Club 103:201-206.

BERGER, A. 1985. Seed dimorphism and germination behaviour in Salicornia patula. Vegetatio 61:137-143.

CODY, M.L. \& CODY, T.W.D. 2004. Morphology and spatial distribution of alien sea-rockets (Cakile spp.) on South Australian and Western Canadian beaches. Australian Journal of Botany 52:175-183.

CORDAZZO, C.V. 1985. Taxonomia e ecologia da vegetação das dunas costeiras ao sul do Cassino (RS). Dissertação de Mestrado, Universidade do Rio Grande, Rio Grande.

CORDAZZO, C.V. 1994. Comparative population studies of four dominant plants of southern Brazilian coastal dunes. Ph.D. Thesis, Norwich, University of East Anglia.

CORDAZZO, C.V. 2002. Effect of seed mass on germination and growth in three dominant species in southern Brazilian coastal dunes. Brazilian Journal of Biology 62:427-435.

CORDAZZO, C.V. \& DAVY, A.J. 1994. Seed production and seed quality of the dune building grass Panicum racemosum Spreng. Acta Botanica Brasilica 8:193-203.

CORDAZZO, C.V. \& SEELIGER, U. 1993. Zoned habitats of southern Brazilian coastal Foredunes. Journal of Coastal Research 9:317-323.

COSTA, C.S.B., SEELIGER, U. \& CORDAZZO, C.V.1991. Leaf demography and decline of Panicum racemosum populations in coastal foredunes of southern Brazil. Canadian Journal of Botany 69:1593-1599.

DAVY, A.J. \& FIGUEROA, E. 1993. The colonization of strandlines. In Primary succession on land (J. Miles \& D.W.H. Walton, eds.). Blackwell Scientific Publications, Oxford, p.113-131.

DONOHUE, K. 1998. Maternal determinants of seed dispersal in Cakile edentula: fruit, plant, and site traits. Ecology 79:2771-2788. 
ERNEST, W.H.O. 1985. Some considerations and perspectives in coastal ecology. Vegetatio 62:533-545.

FENNER, M. 1985. Seed ecology. Chapman \& Hall, New York.

GARCIA-NOVO, F. 1976. Ecophysilogical aspects of the distribution of Elymus arenarius and Cakile maritima on the dunes of Tent Muir point (Scotland). Ecologia Plantarum 11:13-24

GUPPY, H.B. 1917. Plants, seeds and currents in the West Indies and Azores. Williams and Norgate, London.

HARPER, J.L. 1977. Population biology of plants. Academic Press, London.

HAWKE, M.A. \& MAUN, M.A. 1989. Intrapopulation variation in reproduction and seed mass of a beach annual; Cakile edentula var. lacustris. Journal of Coastal Research 5:103-112.

HOCKING, P.J. 1982. Salt and mineral nutrient levels in fruits of two strand species, Cakile maritima and Arctotheca populifolia, with special reference to the effect of salt on the germination of Cakile. Annals of Botany 50:335-343.

IGNACIUK, R. \& LEE, J.A. 1980. The germination of four annual strand-line species. New Phytologist 84:581-591.

JANZEN, D.H. 1978. Inter-and-intra-crop variation in seed weight of Costa Rican Ateleia herbert-smithii Pitt. (Leguminosae). Brenesia 14/15:311-323.

KEDDY, P.A. 1980. Population ecology in an environmental mosaic: Cakile edentula on a gravel bar. Canadian Journal of Botany 58:1095-1100.

KEDDY, P.A. 1981. Experimental demography of the sanddune annual Cakile edentula, growing along an environmental gradient in Nova Scotia. Journal of Ecology 69: 615-630.

KEDDY, P.A. 1982. Population ecology on an environmental gradient: Cakile edentula on a sand dune. Oecologia 52:348-355.

MAUN, M.A. 1985. Population biology of Ammophila breviligulata and Calamovilfa longifolia on Lake Huron sand dunes. I. Habitat, growth form, reproduction, and establishment. Canadian Journal of Botany 63:113-124.

MAUN, M.A. \& PAYNE, A.M. 1989. Fruit and seed polymorphism and its relation to seedling growth in the genus Cakile. Canadian Journal of Botany 67:2743-2750.
MAUN, M.A., BOYD, R.S. \& OLSON, L. 1990. The biological flora of coastal dunes and wetlands. 1. Cakile edentula (Bigel.) Hook. Journal of Coastal Research 6:137-156.

PAKEMAN, R.J. \& LEE, J.A. 1991a. The ecology of the strandline annuals Cakile maritima and Salsola kali. I. Environmental factors affecting plant performance. Journal of Ecology 79:143-154.

PAKEMAN, R.J. \& LEE, J.A. 1991b. The ecology of the strandline annuals Cakile maritima and Salsola kali. II. The role of nitrogen in controlling plant performance. Journal of Ecology 79:155-166.

PAYNE, A.M. \& MAUN, M.A. 1981. Dispersal and floating ability of dimorphic fruit segments of Cakile edentula var. lacustris. Canadian Journal of Botany 59:2595-2602.

RODMAN, J.E. 1974. Systematics and evolution of the genus Cakile (Cruciferae). Contributions from the Gray Herbarium, Harvard University 4:3-146.

RODMAN, J.E. 1986. Introduction, establishment and replacement of sea-rockets (Cakile, Cruciferae) in Australia. Journal of Biogeography 13:159-171.

SALISBURY, E.J. 1942. The reprodutive capacity of plants. Bell and Sons, London.

SEELIGER, U. 1992. Coastal foredunes of southern Brazil: physiography, habitats, and vegetation. In Coastal plant communities of latin America (U. Seeliger, ed.). Academic Press, San Diego, p.367-381.

SORENSON, A.E. 1978. Somatic polymorphism and seed dispersal. Nature 276:174-176.

WATKINSON, A.R. 1985. On the abundance of plants along an environmental gradient. Journal of Ecology 73:569-578.

WATKINSON, A.R. \& DAVY, A.J. 1985. Population biology of salt marsh and sand dune annuals. Vegetatio 62:487-497.

WILLIAMS, J.T. \& HARPER, J.L.1965. Seed polymorphism and germination. I. The influence of nitrates and low temperatures on the germination of Chenopodium album. Weed Research 5:141-150.

ZAR, J.H. 1984. Biostatistical analysis, $2^{\text {nd }}$ ed. Prentice Hall, Englewood Cliffs, New Jersey.

ZHANG, J. \& MAUN, M.A. 1992. Effects of burial in sand on the growth and reproduction of Cakile edentula. Ecography 15:296-302 